\title{
Detection of Rhynchosporium secalis in barley seeds from Argentina through polymerase chain reaction technique
}

\author{
Melina Ocampo Ríos ${ }^{1}$, Paula Fernández ${ }^{2} \&$ Marcelo Carmona $^{1}$ \\ ${ }^{1}$ Faculdad de Agronomía, Universidad de Buenos Aires, Av. San Martín 4453 (1417) Buenos Aires, Argentina; ${ }^{2}$ C.I.C.V y A. \\ Instituto de Biotecnología. INTA Castelar. Las Cabañas y Los Reseros S/N (1712). Villa Udaondo. \\ Pcia. de Buenos Aires, Argentina, pfernandez@cnia.inta.gov.ar
}

Autor para correspondencia: Paula Fernández

RÍOS, M.O., FERNÁNDEZ, O. \& CARMONA, M. Detection of Rhynchosporium secalis in barley seeds from Argentina through polymerase chain reaction technique. Fitopatologia Brasileira 32:415-418. 2007.

\begin{abstract}
Leaf scald of barley caused by Rhynchosporium secalis is an important disease in Argentina. The fungus is a necrotrophic pathogen which survives in stubble, seeds and weeds. Isolation of $R$. secalis from seeds on artificial media usually has not been successful due to the slow growth rate of the pathogen and strong inhibition by contaminants. The objective in this work was to detect $R$. secalis in different genotypes of barley seeds in Argentina using the polymerase chain reaction (PCR)-based diagnostic assay. Four barley genotypes were tested in 2004: Quilmes Ayelén, Quilmes Alfa, Barke and Maltería Pampa 1004. The previously described RS8 and RS9 primers were used for the detection of $R$. secalis in barley seeds. A 264-bp single band was obtained for each cultivar showing the presence of $R$. secalis. The use of specific primers was efficient in the detection of $R$. secalis in barley seeds in Argentina and could be used for routine diagnosis, epidemiology and seed transmission studies. This is the first report on the detection of $R$. secalis in barley seeds in Argentina.
\end{abstract}

Additional keywords: Hordeum vulgare, diagnosis, PCR.

\begin{abstract}
RESUMEN
Detección de Rhynchosporium secalis en semillas de cebada de Argentina através de la técnica de la reacción en cadena de la polimerasa

La escaldadura de la cebada causada por Rhynchosporium secalis es una importante enfermedad de la cebada en Argentina. El patógeno es necrotrófico y sobrevive en rastrojos, semillas y malezas. La detección de este patógeno por los análisis sanitarios de semilla tradicionales no son exitosos debido principalmente a su lento crecimiento y a la alta contaminación de otros microorganismos. El objetivo de este trabajo fue detectar $R$. secalis en diferentes genotipos de cebada usando la técnica de la reacción en cadena de la polimerasa (PCR). Cuatro genotipos de cebada fueron evaluados en 2004: Quilmes Ayelén, Quilmes Alfa, Barke y Maltería Pampa 1004. Se utilizaron los oligonucleótidos previamente descriptos RS8 y RS9. Como resultado se obtuvo una banda única de 264-pb en cada cultivar indicando la presencia de R. secalis. Esta técnica de detección provee más beneficios que los métodos rutinarios de detección y podría ser una herramienta útil para estudios de diagnóstico epidemiológicos y de transmisión del patógeno Este es el primer reporte sobre la detección de $R$. secalis en semillas de cebada en Argentina.
\end{abstract}

Palabras-clave adicionales: Hordeum vulgare, diagnóstico, PCR.

\section{INTRODUCTION}

Barley (Hordeum vulgare L.) is one of the most important crop plants in Argentina due to the uppermost spread in the last few years as a result of malting exports to Brazil, integration into the Mercosur and the increase in domestic beer consumption. Barley scald caused by Rhynchosporium secalis (Oudem) J.J. Davis has been recognized as one of the most important diseases of barley due to its high level of prevalence, incidence and severity (Carmona \& Barreto, 1995) (Figure 1). In the last surveys carried out in 2003, scald was confirmed as the most important disease for the southern pampeana region of Argentina (Carmona \& Barreto, 2003). The main sources of $R$. secalis inoculum are seeds, infected crop residues and weed grasses, where the parasite remains viable in the saprophytic stage between the crop cycles (Caldwell, 1937; Skoropad, 1959). Seeds are the most efficient mean of fungus spread for both short and long distance. Although the microflora of barley grains has been investigated in Argentina, no seed infection by $R$. secalis was observed (Barreto \& Carmona, 1993). The recovering of $R$. secalis from barley seeds in an artificial medium generally has not been successful due to the natural slow growth of the pathogen and the presence of contaminants (Kay \& Owen, 1973). This is probably the reason why it has not been detected yet on seeds in Argentina (Barreto \& Carmona, 1993). An assay carried out using polymerase chain reaction (PCR) allowed the detection of small concentrations of a specific DNA in a complex environment (Henson \& French, 1993). PCR is highly sensitive 


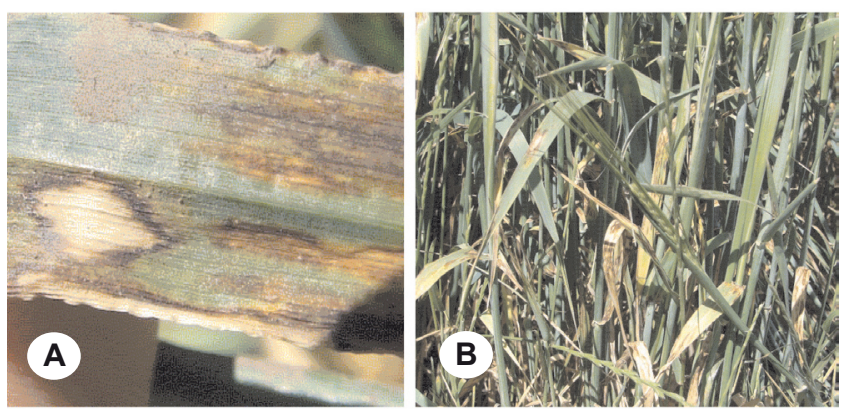

FIG. 1 - Typical scald lesion on leaf (A) and barley field (B).

and reproducible for amplification of diagnostic molecular markers and is used in detection of several pathogens. Lee et al. (2001) developed a PCR assay that successfully detected $R$. secalis in barley seeds, but barley samples from Argentina were not assessed. Among the primers designed, the RS8 and RS9 were the most efficient for the detection and discrimination of $R$. secalis. The objective in this work was to evaluate the presence of $R$. secalis in seeds of different genotypes of barley from Argentina using the polymerase chain reaction (PCR)-based diagnostic assay.

\section{MATERIALS AND METHODS}

\section{Seed sampling}

Four barley seeds genotypes were analyzed: Quilmes Ayelén, Quilmes Alfa, Barke and Maltería Pampa 1004, during the 2001-2002 season. The first three genotypes were collected in Tres Arroyos (Buenos Aires province) and the fourth one in an experimental field at Maltería Pampa (a malt producer company) in Coronel Suárez (Buenos Aires Province).

\section{DNA extraction and PCR}

Seed samples were ground to a powder in liquid nitrogen with mortar and pestle. DNA extraction was performed using CTAB based buffer from pools of 3-4 barley seeds and analyzed in a $1.5 \%$ agarose gel, then quantified in a GeneQuant pro spectrophotometer (Amersham Pharmacia, UK) in order to estimate the DNA concentration and purity (Sambrook et al., 1989).

Primers RS8 and RS9, previously described by Lee et al. (2001) were used for $R$. secalis detection in barley seeds. These primers amplify a specific fragment of $264 \mathrm{bp}$ from $R$. secalis genome. We amplified actine as a positive housekeeping gene control (upper actine: 5'GTGTTGGACTCTGGTGATGG3' (20 nucleotides, $\mathrm{Tm}=55^{\circ} \mathrm{C}$; designed upon 552 to $571 \mathrm{bp}$ actine sequence: lower actine: 5'GGAAGCTCGTAGCTCTTCTC3'Tm $=55^{\circ} \mathrm{C}, 20$ nucleotides). In all cases we performed dilutions ( $1: 10$, 1:20 and 1:50) in order to reduce inhibitor effects of PCR.

Amplifications were performed on a PT-100 DNA thermocycler (MJ Research, USA). PCR master mix contained 10x PCR reaction buffer, $3.5 \mathrm{mM} \mathrm{MgCl} 2,10 \mathrm{mM}$ dNTPs (Invitrogen USA) and 0.5U Taq DNA polymerase (Invitrogen
USA). PCR was performed under the following conditions: $94^{\circ} \mathrm{C}(30 \mathrm{~s})$ denaturing step followed by 27 cycles each consisting of a denaturation step at $94^{\circ} \mathrm{C}(30 \mathrm{~s})$, an annealing step at $66^{\circ} \mathrm{C}(30 \mathrm{~s})$ and extension at $72^{\circ} \mathrm{C}$ for $2 \mathrm{~min}$, and a final extension step at $72^{\circ} \mathrm{C}(10 \mathrm{~min})$.

\section{RESULTS AND DISCUSSION}

According to Lee et al. (2001) PCR products from undiluted DNA templates of each cultivar with RS8 and RS9 primers have not been observed by electrophoresis. However, when DNA dilutions were carried out, a single band was observed in each of them. Inhibitor effects of PCR reaction, commonly found in DNA extracts of vegetal material were overcome by DNA dilutions from 10-to 100 -fold. The band size detected (Figure 2) was 264 in size, thus showing that primers amplified fungal DNA and that such fungus might be found in seeds. Likewise, we observed some differences in the band intensity among cultivars for each dilution, possibly due to differences in seed infection or different inoculum quantities present in seeds among cultivars. These differences in band intensities between cultivars could be explained by different infection percentages of the seeds with $R$. secalis (Parry \& Nicholson, 1996; Lee et al., 2001; Lee et al., 2002). Differences in band intensities for the same cultivar were also observed, as expected, among the three dilutions carried out (Figure 2).

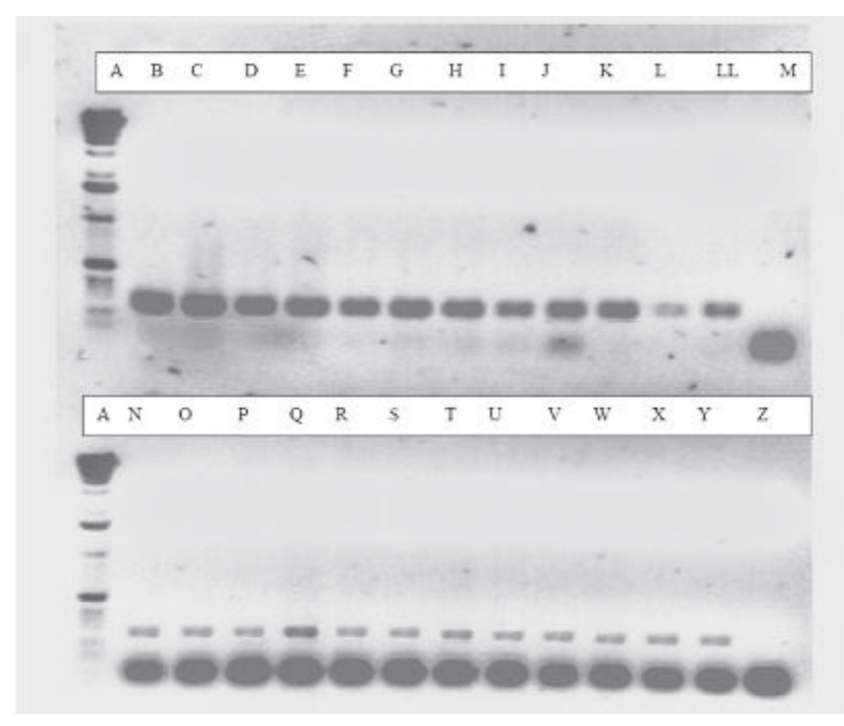

FIG. 2 - Detection of R. secalis in barley seeds from Argentina. A. $1 \mathrm{~Kb}$ molecular marke); B., C and $\mathbf{D}$. Ayelén cultivar dilutions 1:10, 1:20 and 1:50; E, F and $\mathrm{G}-$ Barke cultivar dilutions 1:10, 1:20 and 1:50); H., I and J. Alfa cultivar dilutions 1:10, 1:20 and 1:50; K., L and LL. MP1004 cultivar dilutions 1:10, 1:20 and 1:50; M. RS8 and RS9 primers negative control; N., $\mathbf{O}$ and P. Ayelén; Q., R and S. Barke; T., U and V. Alfa; W., X and Y. MP1004; Z. negative housekeeping gene control. 
According to Barreto \& Carmona 1993, R. secalis is not detected in seeds in Argentina by routine seed testing. However, Carmona et al. (1999) have not detected foliar scald infection either in fields without barley stubble nor secondary hosts showing seeds as a representative inoculum source. In this work, PCR technique applied to seed pathogen detection evidenced that infected seeds could be important for $R$. secalis survival and spread starting primary foci in epidemics of scald in Argentina. In addition, it may be responsible for the introduction of new $R$. secalis strains into new areas (Salamanti et al., 2000).

Even though $R$. secalis external symptoms observations were reported (Lee et al., 2001) scald symptoms are confusing and symptomless seeds can be overlooked (Kay \& Owen, 1973; Lee et al., 1999b). In Argentina, similar symptoms of scald were observed in seed, but the causal agent was Fusarium poae (Peck) Wollenw and not $R$. secalis as expected (Barreto et al., 2004).

$R$. secalis barley seeds infection commonly occurs when grain filling is exceeded in the floral bracts (Skoropad, 1959). This often happens in the lemma, immediately below the awn base. Other few incidences were detected in the palea. Typical lesions of scald represent a light centre and dark brown edges about 6-10 days after symptom appearance although infections do not always take place during the barley milky development stage to show scald symptoms in the lemma or palea external surface. However, the mycelium is present in the inner part of the floral bract surface as well as in the pericarp external surface and serves as a hidden source of primary inoculums. According to Doohan et al. (1998) and Lee et al. (2001) PCR assay is able to detect a pathogen before symptoms arise even in symptomless seeds.

Lee et al. (1999a) reported fungal isolation in lima bean agar in Canada as another diagnosis alternative. Scald symptoms was distributed over the lemmas, paleas, awns, glumes and rachises of the lima bean. By this method, the authors published the first report on successful isolation of the scald fungus from infected barley seed.

This is why the isolation of $R$. secalis through traditional method is recommended as an alternative one when no other methodology is available, taking into consideration the natural slow-growth rate of the pathogen. Polymerase chain reaction has been vastly used as a diagnosis method to make the detection of extremely small quantities of DNA. Due to the wide amplifying efficiency, PCR has been applied for the detection and quantification of $R$. secalis in barley(Lee et al., 2002).

The use of specific primers was efficient in the detection of $R$. secalis in barley seeds in Argentina and could be used for routine diagnosis, epidemiology and seed transmission studies. The use of this technique for $R$. secalis detection could be used as a fast and reliable method to certify barley seeds in Argentina, thus avoiding the dissemination of the pathogen to new production areas in the country. This is the first report on the detection of $R$. secalis in barley seeds in Argentina.

\section{LITERATURE CITED}

BARRETO, D.E. \& CARMONA, M. Microflora of barley and malt in Argentina. Proceedings 1st. ISTA Plant Disease Committee Symposium on Seed Health Testing. Ottawa, Canadá, pp. 7074. 1993.

BARRETO, D., CARMONA, M., FERRAZINI, M., ZANELLI, M. \& PÉREZ, B.A. Occurrence and pathogenicity of Fusarium poae in barley in Argentina. Cereal Research Communications 32:53-60. 2004

CALDWELL, R.M. Rhynchosporium sp. scald of barley, rye, and other grasses. Journal Agriculture Research 55:175-198. 1937.

CARMONA, M.A. \& BARRETO, D.E. Manejo integrado de enfermedades de cebada. Actas, Taller sobre oportunidades para la articulación entre la industria agrícola y la comunidad científica. Facultad de Agronomía. Universidad de Buenos Aires. Octubre 2003. pp. 21-29.

CARMONA, M.A., PIOLI, R. \& REIS, E.M. Malezas hospedantes de hongos necrotróficos causantes de enfermedades en trigo y cebada cervecera en la región pampeana. Rev. Facultad de Agronomía 19:105-110. 1999.

CARMONA, M., \& BARRETO, D. Enfermedades fúngicas en cebada en la provincia de Buenos Aires en 1991. Fitopatologia Brasileira 20:509-510. 1995.

DOOHAN, F.M., PARRY, D.W., JENKINSON, P. \& NICHOLSON, P. The use of species-specific PCR-based assays to analyze Fusarium ear blight of wheat. Plant Pathology 47:197-205. 1998.

HENSON, J.M. \& FRENCH, R. The polymerase chain reaction and plant disease diagnosis. Annual Review Phytopathology 31:81-109. 1993.

KAY, J.G. \& OWEN, H. Transmission of Rhynchosporium secalis on barley grain. Transaction British Mycology Society 60:405-411. 1973.

LEE, H.K., TEWARI, J.P. \& TURKINGTON, T.K. Histopathology and isolation of Rhynchosporium secalis from infected barley seed. Seed Science \& Technology 27:477-482. 1999a.

LEE, H.K., TEWARI, J.P. \& TURKINGTON, T.K. Symptomless infection of barley seed by Rhynchosporium secalis. Annual Meeting Plant Pathology Soc. Alberta. Jasper, Alberta. 1999b.

LEE, H.K., TEWARI, J.P. \& TURKINGTON, T.K. A PCRbased assay to detect Rhynchosporium secalis in barley seed. Plant Disease 85:220-225. 2001.

LEE, H.K., TEWARI, J.P. \& TURKINGTON, T.K. Quantification of seed-borne infection by Rhynchosporium secalis in barley using competitive PCR. Plant Pathology 51:217-224. 2002.

PARRY, D.W. \& NICHOLSON, P. Development of a PCR assay to detect Fusarium poae in wheat. Plant Pathology 45:623-626. 1996.

SALAMANTI, W.P., ZHAN, J., BURDON, J.J. \& MCDONALD, B.A. The genetic structure of field populations of Rhynchosporium secalis from three continents suggests moderate gene flow and regular recombination. Phytopathology 49:623-626. 2000.

SAMBROOK, J., FRITSCH, E.F. \& MANIATIS, T. Molecular 
Cloning: A Laboratory Manual, $2^{\text {nd }}$ Ed. Cold Spring Harbor. Cold Spring Harbor Laboratory Press. Vol. 1. 1989.
SKOROPAD, W.P. Seed and seedling infection of barley by Rhynchosporium secalis. Phytopathology 49:623-626. 1959.

Received 30 October 2006 - Accepted 16 October 2007 - FB 6104 